\title{
Environmental and occupational respiratory diseases - 1037. Sensitization to indoor aeroallergens in pediatric patients
}

\author{
Vanessa Yañez-Perez, Sandra Gonzalez-Diaz, Claudia Gallego-Corella*, Alfredo Arias, Karla Mejía, \\ Luis Alfredo Dominguez, Maricruz Calva, Lorena Rangel, Hilda Hernández
}

From 2nd WAO International Scientific Conference (WISC 2012)

Hyderabad, India. 6-9 December 2012

\section{Background}

Indoor aeroallergens are the main cause of sensitization. The aim of this study is to identify the most common indoor aeroallergens which tested positive by skin tests in Monterrey, México.

\section{Methods}

A retrospective, observational and descriptive study reviewed the skin tests results for indoor aeroallergens in pediatric patients ( $\leq 16$ years) in 2011 . We evaluated the results of skin tests specifically for: Dermatophagoides farinae, Dermatophagoides pteronyssinus, Felis domesticus, Canis familiaris, Blattella germanica and Periplaneta americana.

\section{Results}

A total of 439 skin tests were performed for indoor aeroallergens in pediatric patients. There were $57.6 \%(\mathrm{n}=253)$ men and $42.4 \%(n=186)$ women with mean age of 6.3 years. Patients were divided into the following age-groups: children under 3 years $(17.8 \%, \mathrm{n}=78), 3$ to 5 years $(35 \%$, $\mathrm{n}=154), 6$ to 12 years $(36 \%, \mathrm{n}=158)$ and 13 to 16 years $(11.2 \%, n=49)$. The main diagnoses were chronic rhinopathy $88.9 \%(\mathrm{n}=390)$, asthma $16.7 \%(\mathrm{n}=73)$, atopic dermatitis $4.3 \%(\mathrm{n}=19)$ and other $7.3 \%(\mathrm{n}=32)$. At least $57.9 \%(n=254)$ of the patients had one positive skin test for the evaluated allergens. In these patients, we found sensitization to $D$. farinae in $77.2 \%(\mathrm{n}=196)$, D. pteronyssinus $84.6 \%(\mathrm{n}=215)$, B. germanica $24 \%(\mathrm{n}=61)$, P. American 18.9\% $(\mathrm{n}=48)$, F. domesticus $18.5 \%(\mathrm{n}=47)$, and C. familiaris $10.2 \%(\mathrm{n}=26)$.

\footnotetext{
Allergy and Clinical Immunology, Universidad Autonoma De Nuevo Leon -
} Hospital Universitario "Dr. Jose Eleuterio Gonzalez", Monterrey, Mexico

\section{Conclusions}

$D$. farinae, D. pteronyssinus and B. germanica were the most commonly aeroallergens found at the skin tests. When divided by age, $F$. domesticus and C. familiaris were more frequently found in children less than 3 year. In addition, $D$. farinae and $D$. pteronyssinus were identified more commonly in older age groups.

Published: 23 April 2013

doi:10.1186/1939-4551-6-S1-P36

Cite this article as: Yañez-Perez et al:: Environmental and occupational respiratory diseases - 1037. Sensitization to indoor aeroallergens in pediatric patients. World Allergy Organization Journal 2013 6(Suppl 1):P36.
Submit your next manuscript to BioMed Central and take full advantage of:

- Convenient online submission

- Thorough peer review

- No space constraints or color figure charges

- Immediate publication on acceptance

- Inclusion in PubMed, CAS, Scopus and Google Scholar

- Research which is freely available for redistribution
C Biomed Central

\section{() Biomed Central}

